\title{
Attitude, Self-Concept and Achievement of Junior Secondary School Students in Basic Science in Ekiti State, Nigeria
}

\author{
Dr. Ayodele, Mathew Olagoke \\ Department of Science Education, Faculty of Education, \\ Ekiti State University, Ado-Ekiti, Nigeria \\ E-mail: goksmann@yahoo.com
}

Doi:10.5901/jesr.2016.v6n1p167

\begin{abstract}
This study examined the strength and direction of the relationship between attitude, self-concept and achievement of Junior Secondary Schools students in Basic Science in Ekiti State, Nigeria. The study employed a descriptive of survey type on 360 Junior Secondary Two students selected from nine public secondary schools across the three senatorial districts of Ekiti State, Nigeria, using multistage sampling technique. The instruments used for this study included: Scientific Attitude Inventory (SAl); Self-Concept Scale (SCS) and Basic Science Achievement Test (BSAT). The findings of the study revealed that there was a significant relationship between students' attitude and achievement in Basic Science. The finding also showed that there was a positive and significant relationship between students' self-concept and achievement in Basic Science. It is therefore suggested that teachers should take the advantage of this positive attitude and self-concept to improve their students' achievement in the classroom.
\end{abstract}

Keywords: students' attitude, self-concept, basic science and achievement.

\section{Introduction}

Students' view of science affects the quantity and quality of knowledge acquired in the classroom. Their thoughts about science are the mirror of science education, since it is this very notion that influences their attitude and the way they perceive science and of course learning achievement in school. Science is a weapon for human survival and development and as such, it must be taught to reflect its usefulness to man. In spite of the importance attached to science education in the society, there has been a low level of students' achievement at all levels of education in schools as revealed in public examinations results. This low level of achievement has been an issue of concern to stakeholders in education and the basis of this could not been ascertained, whether it is student or teacher related factor.

A number of the factors could be responsible for low achievement in science. For instance, personality factors such as attitude and self concept. Attitude and self concept play an important role in teaching and learning process, they can affect students' success in science and science related subjects. Attitude according to Karlinger (1970) is a psychological construct, or latent variable, inferred from observable responses to stimuli which are assumed to mediate consistency and coherence among those responses. From the definition above, it could be inferred that attitude is an attribute of personality that can be expressed in terms of likes, or dislikes, interest, values, positive or negative feelings to issues or opinions.

The studies of Fraser and Butts (1982) showed that there was an insufficient evidence to support the claim that attitude and achievement are highly related but research studies have also revealed that a positive relationship do exist between students' attitude and academic achievement. Among the most promising findings of TIMSS 1999, was that, there were positive relationships between students' attitudes towards mathematics and science, although less so in countries where science is taught as separate subjects at the eighth grade (Martin, et al, 2000).

The meta-analysis of research of Weinburg (1995) showed that there was a moderate correlation between attitude towards science and achievement, although this correlation is stronger for high and low ability girls. Similar findings were found in the study conducted by Osborne and Collins (2000). According to Ellis (1996), the attitude of a learner towards science or mathematics will determine his attractiveness or repulsiveness to science or mathematics. This, invariably, will influence the learner's achievement in that subject. He concluded that the attitude of students towards science subjects is related to the achievement in science. To further corroborate the relationship between attitude of students towards sciences and achievement, Martin, et al (2000) emphasized that there was a clear positive association between students' 
attitude towards sciences and science achievement. On average, students with positive attitudes are likely to continue their efforts and willingly perform the learning assignments.

Self concept refers to individual's holistic view about himself that are formed and transformed with individual's own personal experience and others' interpretation of that experience (Kharazi, 2006). According to Klobal and Musek (2008), self concept is an individual's perception of himself; it is a psychological entity and includes one's feeling, evaluation and attitudes, as well as descriptive categories. Self concept is an important construct in education because of its relationship to academic achievement of students.

Several studies have revealed an association between students' self concept and academic achievement. The studies conducted by Valentine, et al (2004), Marsh and Craven, (2006) and Areepattamanni and Freeman (2008) showed a strong associations between students' self concept and academic achievement. Similar researches conducted by Lotfabadi (2004) and Swiaatek (2005) revealed a clear positive relationship between self concept and academic achievement of students. The studies also affirmed that people with a positive self concept acquire more success in areas of social, scientific and occupation. The study of Martin, et al (2000) also substantiates a clear relationship between self concept and science achievement using the TIMSS data. The studies further reiterate that, internationally, 26 percent of students on average developed a high self concept in the sciences.

Conversely, some studies have showed no significant relationship between academic achievement and students' self concept. For instance, Baadjies (2008) in a study on 44 Grade, 9 learners attending St Banabas College in South Africa, the study found that there was no significant correlation between self concept and academic achievement of students. Based on the above contradictory findings on the connections between students' attitude to science, selfconcept and academic achievement, this study is sought to examine the strength and direction of the relationship between attitude, self-concept and achievement of Junior Secondary School students in Basic Science in Ekiti State, Nigeria. On the basis of this, three research hypotheses are generated to guide the study.

\section{Research Hypotheses}

(1) There is no significant relationship between students' attitude and achievement in Basic Science

(2) There is no significant relationship between students' self-concept and achievement in Basic Science

(3) Students' attitude and self-concept will not jointly contribute to their achievement in Basic Science

\section{Methodology}

The study employed a descriptive of survey to examine the relationship between students' attitude, self-concept and achievement in Basic Science.

\subsection{Population}

The population for the study comprised 21,500 Junior Secondary School 2 students from Ekiti State, Nigeria.

\subsection{Sample and Sampling Technique}

The sample for this study was made of 360 Junior Secondary two students selected from nine public secondary schools across the three senatorial districts of Ekiti State, Nigeria, using multistage sampling technique. In the first stage, simple random sampling technique was used to select nine Local Government Areas out of the 16 Local Government Areas of the State. In the second stage, random sampling was used to select two schools each from the nine Local Government Areas selected for the study. The next stage was the selection of 20 students from each school using simple random sampling technique. In all, a total of 360 students was selected and used for the study.

\section{Research Instruments}

The instruments used for this study include: Scientific Attitude Inventory (SAI) adapted from Moore and Foy (1996); SelfConcept Scale (SCS) (Adapted from Rosenberg, 1985 and Marsh, 1992) and Basic Science Achievement Test (BSAT). The adapted inventory and self-concept scale questionnaires was an instruments that was developed and administered to a nationally representative sample which measures both students' general purposes and specific domains such as 
physical activities and peer relations. The instruments consisted of 30 items, 14 items for Scientific Attitude Inventory and 16 items for Self-Concept questionnaire. The Scientific Attitude Inventory was specifically design to address students' interest in science and science activities while self-concept questionnaires was intended to appraise students' relations with peers to physical abilities. A four-point Likert scale was used which include: Strongly Agree $=4$, Agree $=3$, Disagree $=2$ and Strongly Disagree $=1$.

\subsection{Validity of the Instruments}

For the purpose of this study, the face and content validity of the Basic Science Achievement Test (BSAT) was ensured by given the items to two experts in the field of science education, two tests evaluators and two Basic Science teachers who are currently teaching in secondary schools. Their comments were adhered to and the corrected version was used. The Scientific Attitude Inventory (SAI) adapted from Moore and Foy (1996) and Self-Concept Scale (SCS) (Adapted from Rosenberg, (1985) and Marsh, (1992) have been found to be valid and reliable globally but for the benefit of doubt, the adapted portions of the items were submitted to a panel of judges who judged the statements. The panel of judges consisted of 2 science educators from secondary schools, 2 Professors from the Department of Language Education and 2 Test evaluators from the Department of Test, Measurement and Evaluation and their comments were strictly adhered to.

\subsection{Reliability of the Instruments}

The reliability of the instruments was ascertained using test-retest method. This was done by administering the Scientific Attitude Inventory; Self-Concept Scale and Basic Science Achievement Test to a group of 30 students selected from schools not included in the study. The data collected on single administration of the instruments were correlated using split-half reliability formula and a reliability coefficient of $0.76,0.81$ and 0.79 was obtained for SAI, SCS and BSAT respectively. These were considered high and reliable enough for the study.

\subsection{Administration of the Instruments}

To ensure proper administration of the instruments, the Scientific Attitude Inventory and Self-Concept Scale questionnaires was administered to the students with the help of two research assistant and the subject teachers after taken permission from the school principals of the schools selected. In subsequent contact with the students, Basic Science Achievement Test was administered on them and the data collected were analyzed using Pearson's Product Moment Correlation and Multiple Regression analysis using SPSS version 16 at 0.05 level of significance.

\section{Results and Discussion}

\subsection{Hypothesis One}

There is no significant relationship between students' attitude and achievement in Basic Science

To test this hypothesis, Pearson's product moment correlation analysis was used to test the relationship between students' attitude and achievement in Basic Science.

Table 1: Pearson correlation of students' attitude and achievement in Basic Science

\begin{tabular}{|l|c|c|c|c|c|}
\hline Variable & $\mathrm{N}$ & Mean & SD & $\mathrm{r}$ & $\mathrm{P}$ \\
\hline Students' Attitude & 360 & 49.16 & 5.10 & \multirow{2}{*}{$0.432^{*}$} & \multirow{2}{*}{0.000} \\
\hline Achievement in Basic Science & 360 & 12.71 & 3.25 & \\
\hline${ }^{*} \mathrm{P}<0.05$
\end{tabular}

Table 1 shows that there was a low, positive and significant relationship between students' attitude and achievement in Basic Science $(r=0.432, p<0.05)$. The null hypothesis which states that, there is no significant relationship between students' attitude and achievement in Basic Science was rejected. This implies that there was a significant relationship between students' attitude and achievement in Basic Science. 


\subsection{Hypothesis Two}

There is no significant relationship between students' self-concept and achievement in Basic Science

To test this hypothesis, Pearson's product moment correlation analysis was used to test the relationship between students' self-concept and achievement in Basic Science.

Table 2: Pearson's correlation of students' self-concept and achievement in Basic Science

\begin{tabular}{|l|c|c|c|c|c|}
\hline Variable & $\mathrm{N}$ & Mean & SD & R & P \\
\cline { 1 - 4 } Students' self-concept & 360 & 54.74 & 5.71 & \multirow{2}{*}{$0.599^{*}$} & \multirow{2}{*}{0.000} \\
\hline Achievement in Basic Science & 360 & 12.71 & 3.25 & \\
\hline${ }^{*} \mathrm{P}<0.05$
\end{tabular}

Table 2 shows that there was a positive and significant relationship between students' self-concept and achievement in Basic Science $(r=0.599, p<0.05)$. The null hypothesis which states that, there is no significant relationship between students' self-concept and achievement in Basic Science was rejected. This implies that there was a significant relationship between students' self-concept and achievement in Basic Science.

\subsection{Hypothesis Three}

Students' attitude and self-concept will not jointly contribute to their achievement in Basic Science

To test this hypothesis, multiple regression analysis was used to analyze the joint contribution of students' attitude and self-concept to achievement in Basic Science.

Table 3: Multiple regression analysis of students' attitude and self-concept on achievement in Basic Science

\begin{tabular}{|c|c|c|c|c|c|c|c|c|}
\hline Model & B & SE & Beta & $T$ & Sig. $T$ & $\mathbf{R}$ & $\mathbf{R}^{2}$ & $F$ \\
\hline Constant & -5.517 & 1.484 & & -3.717 & 0.000 & \multirow{3}{*}{0.566} & \multirow{3}{*}{0.320 * } & \multirow{3}{*}{84.142} \\
\hline Attitude & 0.084 & 0.036 & 0.132 & $2.344^{*}$ & 0.020 & & & \\
\hline Self-concept & 0.259 & 0.031 & 0.472 & $8.376^{*}$ & 0.000 & & & \\
\hline
\end{tabular}

The result in table 3 reveals that attitude and self-concept jointly contribute to students' achievement in Basic Science ( $F$ $=84.143, \mathrm{P}<0.05)$. The null hypothesis which states that students' attitude and self-concept would not jointly contribute to their achievement in Basic Science was rejected. Thus, there was a significant multiple correlation between students' attitude, self-concept and achievement in Basic Science $(r=0.566, p<0.05)$. Students' attitude and self-concept jointly explained about $32 \%\left(r^{2}=0.32\right)$ of the variance in students' achievement in Basic Science. The remaining $68 \%$ unexplained variation is largely due to other variables outside the regression model. The effect of students' attitude $(\mathrm{t}=$ 2.344, $p<0.05)$ and self-concept $(t=8.376, p<0.05)$ on students' achievement in Basic Science is statistically significant at 0.05 level in each case. Self-concept is a better predictor of students' achievement in Basic Science with a beta weight of $0.473(47.3 \%)$ than students' attitude (beta weight $=0.132 ; 13.2 \%$ ).

\section{Discussion}

The findings of this study revealed a low, positive and significant relationship between students' attitude and achievement in Basic Science. The result indicated that most of the students appeared to have developed positive attitude towards learning Basic Science. The finding was in line with the findings of Osborne and Collins, (2000) and Martin, et al (2000) whose studies showed a significant and positive relationship between attitude of students towards sciences and achievement.

The result of the study also showed a positive and significant relationship between students' self-concept and achievement in Basic Science. The finding agreed with the findings of Valentine, et al (2004), Marsh and Craven, (2006) and Areepattamanni and Freeman, (2008) that there was a strong association between students' self concept and academic achievement. The finding also corresponds with the findings of Lotfabadi (2004) and Swiaatek (2005) whose studies revealed a clear positive relationship between self concept and academic achievement of students.

The finding of the study further revealed a significant multiple correlations between students' attitude, self-concept and achievement in Basic Science. This finding agreed with the findings of Marsh and Craven (2006) whose studies revealed a positive and significant correlations between academic achievement in students self concept. The result of the 
study also agreed with the findings of Swiaatek (2005) whose study revealed a clear positive relationship between self concept and academic achievement of students. The studies also affirmed that people with a positive self concept acquire more success in areas of social, scientific and occupation. The findings of this study showed a divergence from the findings of Baadjies (2008) whose study found no significant correlation between self concept and academic achievement of students. Generally, the overall effect of students' attitude and self-concept on achievement in Basic Science is statistically significant.

\section{Implication of the Study}

The results of the study indicated that there was a positive and significant multiple correlations between students' attitude, students' self-concept and achievement in Basic Science. The results suggests that the students had positive drive to achieve significantly in science and science related subjects after leaving Junior Secondary Schools.

\section{Recommendation}

With students' positive attitude and self-concept about Basic Science, it is important for teachers to take the advantage of this positive attitude and self-concept to improve their students' achievement in the classroom.

\section{Conclusion}

The main objective of this paper is to examine the strength and direction of the relationship between attitude, selfconcept and achievement of Junior Secondary School students in Basic Science in Ekiti State, Nigeria. From the findings of this study, it is concluded that a positive students' attitude and self-concept will go a long way in improving their achievement in Basic Science. Therefore, teachers must assist their students in this direction to further develop right attitude and self-concept towards the subject.

\section{References}

Areepattamannil, S. and Freeman, J. G. (2008). Academic achievement, academic self-concept, and academic motivation of immigrant. Adolescent in the greater Toronto Area Secodary Schools. Journal of Advanced Academics, 19, 4, $700-743$.

Baadjies, L. (2008). Self concept and academic achievement of Grade 9 Pupils. Unpublished M. Ed dissertation Johannesburg: University of Johannesburg.

Ellis, A. A. M. (1996). Belief, Attitude, Intention and Behaviour: An Introduction to Theory and Research. Educational Studies, 26, 243 254.

Fraser, B., and Butts, W. L, (1982). Relationship between perceived levels of classroom individualization and science related attitudes. Journal of research in science teaching, 19, 143-154.

Karlinger, F. N. (1970). Foundation of Behavioural Research. Northridge. 484

Klobal, D. and Musek, J. (2001). Self concept and academic achievement: Slovenia and France. Personality and Individual Differences, $30,887-889$.

Lotfabadi, H. (2004). Educational Psychology. Tehran University Press,..Tehran.

Marsh, H. W, and Craven, R. G (2006). Reciprocal effects of self concept and performance from a multidimensional perspective: beyond seductive pleasure and one-dimensional perspectives. Perspectives on Psychological Sciences, 1, 2, 133-163.

Marsh, H. (1992). Self-Description Questionnaire 11: Manual Publication Unit. Faculty of Education. University of Western Sydney.

Martin, M, Mullis, I, Gozalez, E, Gregory, K, Smith, T, Chrostowski, S, Garden, R, and O'Connor, K. (2000). TIMSS 1999, International Science Report.

Moore, RW and Foy, RLH. (1997). The scientific attitude inventory: A revision (SAI II) Journal of Research in Science Teaching, 34, 4, 327-336.

Osborne, JF and Collins, S. (2000). Pupil's and parents' views of the school science curriculum (London: King's College London).

Rosenberg, M. (1985). Self-concept and psychological well-being in Adolesence. In Development of the self. Edited by R. L. Leahy. Orlando, FL: Academic Press. 205-246.

Swiaatek, MA. (2005). Gifted students' self-perception of ability in specific subject domains: Factor structure and relationship with abovelevel test scores. Paper Review. Bloomfield Hills, 27, 104-106.

Valentine, J. C, Dubios, D. L, and Cooper, H. (2004). The relations between self-belief and academic achievement: A systematic review. Educational Psychologist, 39, 2, 111-133.

Weinburgh, M. (1995). Gender differences in student attitude towards science: a meta-analysis of the literature from 1970 to 1991. Journal of Research in Science Teaching, 32, 389-398. 